\title{
Treated wastewater outperformed freshwater for barley irrigation in arid lands
}

\author{
Nezar H. Samarah, ${ }^{1}$ Khaled Y. Bashabsheh, ${ }^{1,2}$ Naem T. Mazahrih ${ }^{2}$ \\ ${ }^{1}$ Department of Plant Production, Jordan University of Science and Technology, Irbid; ${ }^{2}$ National \\ Agricultural Research Center (NARC), Baq'a, Jordan
}

\begin{abstract}
The high demand of barley for animal feed and the scarcity of fresh water increase the need for the reuse of treated wastewater as an alternative source for irrigation. Therefore, two-field experiments were conducted to study physiological processes, plant growth, grain yield and yield components of four-barley cultivars grown under four-irrigation treatments using treated wastewater or fresh water. Plants of four-barley cultivars (ACSAD176, Rum, Athroh, Yarmouk) were exposed to four-irrigation treatments: i) Full-irrigation using treated wastewater (FWW); ii) Supplementary-irrigation using treated wastewater (SWW); iii) Supplementary-irrigation using fresh water (SFW); 4) Non-irrigation treatment (Rainfed). Full- or supplementary-irrigation using treated wastewater reduced stomatal resistance and increased plant photosynthetic rate, plant height, grain yield and yield components as estimated by grain number plant $^{-1}$ and 1000 -grain weight compared with rainfed conditions. Plants grown under supplementary-irrigation using treated wastewater produced higher grain yield than those grown under supplementary-irrigation using fresh water. Rum cultivar had the highest grain yield among cultivars grown under irrigation. Under rainfed conditions, Rum and ACSAD176 had the highest grain yield. In conclusion, supple-
\end{abstract}

Correspondence: Nezar H. Samarah, Department of Plant Production, Jordan University of Science and Technology, P.O. Box 3030 Irbid, 22110, Jordan.

E-mail: nsamarah@just.edu.jo

Key words: Treated wastewater; barley; supplementary irrigation; heavy metals; water scarcity; photosynthetic rate; stomatal resistance.

Acknowledgements: This study was supported by Deanship of Research at Jordan University of Science and Technology under grand No. (20100254). Thanks are also extended to the National Agricultural Research Center (NARC) for carrying out the mineral analysis in soil and grain.

Received for publication: 21 February 2020.

Revision received: 25 May 2020.

Accepted for publication: 29 May 2020.

${ }^{\circ}$ Copyright: the Author(s), 2020

Licensee PAGEPress, Italy

Italian Journal of Agronomy 2020; 15:1610

doi:10.4081/ija.2020.1610

This article is distributed under the terms of the Creative Commons Attribution Noncommercial License (by-nc 4.0) which permits any noncommercial use, distribution, and reproduction in any medium, provided the original author(s) and source are credited. mentary-irrigation using treated wastewater improved grain yield of barley and can be a better choice to conserve water and reduce the risk of plant lodging at the end of the growing season. Irrigation of barley using treated wastewater did not change heavy metal $(\mathrm{Zn}, \mathrm{Cd}$, and $\mathrm{Pb})$ concentrations in soil or harvested grains.

\section{Introduction}

Barley is the fourth most important cereal crop in the world after wheat, maize, and rice. Similar to other cereal crops, barley plants experience a severe-drought stress during growth and development, which is considered as the main constraint to crop productivity (Samarah et al., 2009; Sabagh et al., 2019). Water scarcity is the major challenge in developing countries including Jordan, which is considered as one of the most water-scarce countries in the world (Abu-Sharar and Battikhi, 2002; Scott et al., 2003; Rijsberman, 2006). To face water scarcity, several strategies have been developed to conserve water resources and search for other resources (Scott et al., 2003; Sakellariou-Makrantonaki et al., 2007; Pedrero et al., 2010). Treated wastewater reuse for agriculture has been rapidly rising worldwide and considered as the greatest challenge, particularly in developing countries (Bouwer, 2000; Bazza, 2003; Zhang and Shen, 2019). The use of treated wastewater for agricultural irrigation is highly encouraged as an alternative source of water and nutrients for improving plant growth and yield, recycling of water, and reducing the use of fresh water (Mohammad and Mazahreh, 2003; Mañas et al., 2009; Pedrero et al., 2010; Dery et al., 2019; Etchebarne et al., 2019; Murtaza et al., 2019; Jahany and Rezapour, 2020; Pandey and Saxena, 2020).

Many studies have reported the importance of using wastewater in crop production such as barley, corn, vetch, wheat, eggplant, and pepper (Erfani et al., 2001; Meerbach et al., 2005). Al-Hadidi (2009) showed that there was a significant increase in barley biological yield (grain and straw yield) when barley plants were irrigated with treated wastewater. Irrigation using treated wastewater increased the yield of corn (Zea mays) and vetch (Vicia sativa) (Khattari and Jamjoum, 1988; Erfani et al., 2001; Mohammad and Ayadi, 2004; da Fonseca et al., 2005). Khattari and Jamjoum (1988) reported that high-quality treated wastewater could be used in irrigation of economic crops. Grain yield of wheat, maize, millet, rapeseed, and yellow beans in plots irrigated with treated wastewater were much higher than of those in dry farming, suggesting that the treated wastewater was able to supply the crops with water and essential nutrients (Wang et al., 2007). Treated wastewater increased yield of cauliflower (Brassica olerecea L.), red cabbage (Brassica olerecea L.) (Kiziloglu et al., 2008), and five-crop species (Zavadil, 2009). Alderfasi (2009) indicated that irrigation with treated wastewater increased plant growth, grain yield and yield components, and grain protein of two wheat geno- 
types compared with fresh water. Alikhasi et al. (2012) found that cotton yield, number of bolls per $\mathrm{m}^{2}$, leaf area index, and plant height were significantly higher in plants irrigated with treated wastewater than those irrigated with fresh water. Wheat plants irrigated with wastewater showed an increase in all yield parameters including grain yield, straw yield, 1000-grain weight, spike length, plant height, and number of tillers compared to fresh water (Rahimi et al., 2012). Al-Karaki (2011) showed that barley produced in a hydroponic system using treated wastewater had higher fresh- and dry-fodder yields than those produced using fresh water. The barley biomass increased with the nutrients provided with the wastewater (Rusan et al., 2007).

Although treated wastewater contains substantial amounts of beneficial nutrients for improving plant growth and yield, treated wastewater may contain high level of heavy metals such as $\mathrm{Cd}$ and $\mathrm{Pb}$ and other organic contaminants (Chen et al., 2005; Kalavrouziotis and Koukoulakis, 2012). Using treated wastewater in irrigation can result in accumulation of heavy metals in soil and lead to uptake of these metals by plants grown in contaminated soils (Chen et al., 2005; Khan et al., 2008; Tabari and Salehi, 2009; Khanpae et al., 2020). There was an increase in heavy metals in soil and plants grown under irrigation using wastewater compared with uncontaminated soil (Khan et al., 2008). Wastewater affected soil chemical properties in the $0-30 \mathrm{~cm}$ soil layer by increasing soil salinity, organic matter, and exchangeable $\mathrm{Na}, \mathrm{K}, \mathrm{Ca}, \mathrm{Mg}$ (Kiziloglu et al., 2008). The nutrient content (N, P, K, Ca, Mg, Na, $\mathrm{Fe}, \mathrm{Mn}, \mathrm{Zn}, \mathrm{Cu}, \mathrm{Pb}, \mathrm{Ni}$ and $\mathrm{Cd}$ ) in red cabbage (Brassica olerecea L.) and cauliflower (Brassica olerecea L.) plants irrigated with wastewater were also increased (Kiziloglu et al., 2008). Accumulation of heavy metals was not observed in soil irrigated with treated wastewater (Kiziloglu et al., 2008). Tabari and Salehi (2009) reported that plant analysis of Robinia pseudoacacia L. indicated that concentrations of leaf nutrients of $\mathrm{N}, \mathrm{P}, \mathrm{K}, \mathrm{Ca}, \mathrm{Mg}$, $\mathrm{Na}, \mathrm{Fe}, \mathrm{Mn}, \mathrm{Cu}$, and $\mathrm{Zn}$ were greater in sewage-irrigated trees than those of well water irrigated trees. Accumulation of heavy metals in soil and plants can cause potential risk to human health (Khan et al., 2008; Rezapour et al., 2019).

The high demand of barley for animal feed and the lack of fresh water resources for irrigation increase the need for the beneficial reuse of treated wastewater for barley production in Jordan. Inefficient use of water for irrigation is considered as one of the major constraints leading to slow and uneven reuse of wastewater in agriculture (Qadir et al., 2010). The reuse of treated wastewater to produce barley and how different barley cultivars respond to irrigation using treated wastewater needs to be studied. Therefore, the objectives of this study were to understand the effect of reusing of treated wastewater for barley irrigation on physiological pro- cesses, plant growth and grain yield and to identify barley cultivars with the highest grain yield in response to different irrigation treatments. Another objective was to assess the effect of wastewater on heavy metal content in soil and grain yield.

\section{Materials and methods}

\section{Two field experiments}

Two-field experiments were conducted at two locations, Ramtha Water Treatment Station (Ramtha) and Wastewater Treatment Station at Jordan University of Science and Technology (JUST) during the growing-season of 2010-2011. Both locations have a Mediterranean climate, characterised by cold winter and hot summer. The average annual rainfall and Aridity Index are $275 \mathrm{~mm}$ and 0.138 in Ramtha experimental site and $220 \mathrm{~mm}$ and 0.11 in JUST site, respectively, and the climate of both locations is classified as arid (UNESCO, 1979). The lowest minimum temperature was recorded in January and February $\left(-0.5\right.$ to $\left.0.6^{\circ} \mathrm{C}\right)$, while the highest maximum temperatures $\left(34\right.$ to $\left.38^{\circ} \mathrm{C}\right)$ were recorded in April and May (Table 1). At both locations (Ramtha and JUST), the highest amount of rainfall was recorded in February. The total amount of rainfall in the experimental season was higher at Ramtha (301 mm) than at JUST $(212 \mathrm{~mm})$ (Table 1). Prior to planting, soil was tilled using chisel plow. Seeds of four-barley (Hordeum vulgare L.) cultivars (ACSAD176, Rum, Athroh, and Yarmouk), obtained from the National Agricultural Research Center (NARC), Al-Baq'a, Jordan, were planted on 5 December, 2010 at a seeding rate of $100 \mathrm{~kg} \mathrm{ha}^{-1}$ at both locations. The seeds were planted in rows in $3 \times 5 \mathrm{~m}$ plots with $25 \mathrm{~cm}$ among rows. No fertilisers were applied to sites in any treatment based on the TWW nutrients contents. Weeds were controlled by hands during the growing season. The plants were subjected to four-irrigation treatments: i) Full-irrigation using treated wastewater (FWW); ii) Supplementary-irrigation using treated wastewater (SWW); iii) Supplementary-irrigation using fresh water (SFW); iv) Non-irrigation treatment (Rainfed) (Table 2). Irrigation water was applied using a drip irrigation method and the amount of water applied to each plot in each treatment was monitored using a volumetric water meter installed on the irrigation pipelines. In full-irrigation treatment, water quantity of $10-38 \mathrm{~mm}$ was applied at the following frequencies throughout the 2010-2011 growing season: one time during February, two times during each month of December, January, and March, and four times during April (during flowering, heading, and grain development and maturation). In supplemen-

Table 1. Maximum and minimum temperatures and rainfall at two locations, Ramtha and Jordan University of Science and Technology (JUST), during the growing season 2010-2011.

\begin{tabular}{lcccc} 
Month & Min & $\begin{array}{c}\text { Temperature } \\
\text { Both locations }\end{array}$ & Rax & Rainfall \\
Ramtha & & JUST \\
December & 1.8 & 26.0 & 52.8 & 40.8 \\
January & 0.6 & 19.0 & 59.5 & 22.0 \\
\hline February & -0.5 & 23.4 & 88.0 & 89.5 \\
March & 2.0 & 28.8 & 41.5 & 25.2 \\
\hline April & 5.0 & 34.4 & 54.0 & 12.1 \\
May & 5.0 & 38.4 & 5.6 & 22.1 \\
\hline Total & & & $\mathbf{3 0 1 . 4}$ & $\mathbf{2 1 1 . 7}$ \\
\hline
\end{tabular}


tary-irrigation treatment, water quantity of 16-35 $\mathrm{mm}$ was applied one time in March and two times in April. In both treatments, irrigation quantity and frequency was based on soil moisture conditions using tensiometers and gravimetric soil samples. The three irrigation treatments (full-irrigation, supplementary-irrigation, and rainfed) resulted in three levels of water supply of 534, 370, and $300 \mathrm{~mm}$ in Ramtha and 490, 300, and $211 \mathrm{~mm}$ in JUST, respectively (Table 2).

\section{Photosynthetic rate and stomatal resistance}

Photosynthetic rate and stomatal resistance were measured on 16 March (tillering stage), 2 April (heading stage), 17 April (milking stage), and 7 May, 2011 (grain filling stage) at mid-day for random samples of upper four-healthy leaves in plants to assess their physiological response to the three irrigation treatments. The photosynthetic rate was measured using plant photosynthetic meter (EARS-PPM, Netherlands). Stomatal resistance was measured using a steady state porometer (Li-1600). The EARS-PPM determined the quantum yield of photosynthesis $(\Phi \mathrm{p})$ from two chlorophyll fluorescence measurements: one under ambient light condition (F) while the second one under the maximum fluorescence yield (Fm). The quantum yield is calculated using the following formula:

$\Phi p=1-F / F m$

The quantum yield is related with light level. Therefore, the PPM measures the photosynthetic active radiation (PAR) incident on the leaf at the same time. The simultaneously measured values of $\Phi p$ and PAR enabled the calculation of gross photosynthesis level (P), expressed in the equivalent photon flux density.

$\mathrm{P}=\Phi \mathrm{p} * \mathrm{PAR}$

\section{Plant height and yield components}

Plant height was measured for 10-random plants per replicate in each treatment at the end of the growing season. Plant height was measured from the base of the plant (soil level) to the top of the plant without the awns. Grain yield was measured for harvested plants from a random sample of one-square meter from each plot. Yield components (number of spike plant ${ }^{-1}$ and 1000-grain weight) were measured for a random sample of ten plants taken from the harvested plants.

\section{Soil physical and chemical analysis}

Soil samples from experimental plots were taken at 0-20 cm and 20-40 cm depths before and after planting to characterise the initial soil physical and chemical properties. Soil samples were air dried, ground by mortar, and sieved using a 2-mm sieve. The soil was analysed for the following general properties: $\mathrm{pH}$, electrical conductivity (EC), sodium adsorption ratio (SAR), N, P, K, Mg, $\mathrm{Na}, \mathrm{Ca}, \mathrm{Cd}, \mathrm{Fe}, \mathrm{Zn}$, and $\mathrm{Pb}$. The soil $\mathrm{pH}$ and electrical conductivity (EC) were measured using the $\mathrm{pH}$ and EC Meter at 1:1 soil to water ratio according to McKeague (1978) McLean (1982), respectively. The SAR was calculated according to Foth (1978). The total nitrogen (T-N) was estimated by the Kjeldahl digestion method. Phosphorus (P) was estimated according to Olsen (1954). Extractable potassium was estimated using the flame photometer. Magnesium (Mg), Sodium ( $\mathrm{Na}$ ) and Calcium were estimated in the saturation extract using the Atomic Absorption Spectrometer. The cadmium $(\mathrm{Cd})$, Iron $(\mathrm{Fe})$, Zinc $(\mathrm{Zn})$, and lead $(\mathrm{Pb})$ were extracted from soil with $0.005 \mathrm{M}$ diethylenetriaminepentaacetic acid (DTPA) and measured using Atomic Absorption Spectrophotometer. Available micronutrients and heavy metals were estimated by Standard Methods for the examination of water and wastewater (APHA, 1995).

\section{Grain mineral analysis}

Grains harvested from plants exposed to different irrigation treatments were analysed to determine the concentrations of $\mathrm{P}, \mathrm{K}$, $\mathrm{Zn}, \mathrm{Cd}$, and $\mathrm{Pb}$ at the National Agricultural Research Center (NARC). Seeds were oven-dried at $650^{\circ} \mathrm{C}$ for $72 \mathrm{~h}$ and then ground by a stainless steel grinder to pass a stainless steel sieve of $1 \mathrm{~mm}$ diameter for determination of chemical analysis as described by (AlKhader, 2015). A sample of $1 \mathrm{~g}$ was taken and ashed in a muffle furnace at $5000^{\circ} \mathrm{C}$ for $4 \mathrm{~h}$. The ash was left to cool and then was supplied with $5 \mathrm{ml}$ of $6 \mathrm{~N} \mathrm{HCl}$. The mixture was digested on a hot plate to obtain a clear solution. The residue was dissolved in $0.1 \mathrm{~N}$

Table 2. Amount of water applied to four cultivars of barley grown at two locations (Ramtha and JUST) in full-irrigation treatment using treated wastewater, supplementary-irrigation treatment using treated wastewater or fresh water during the growing season of 2010-2011.

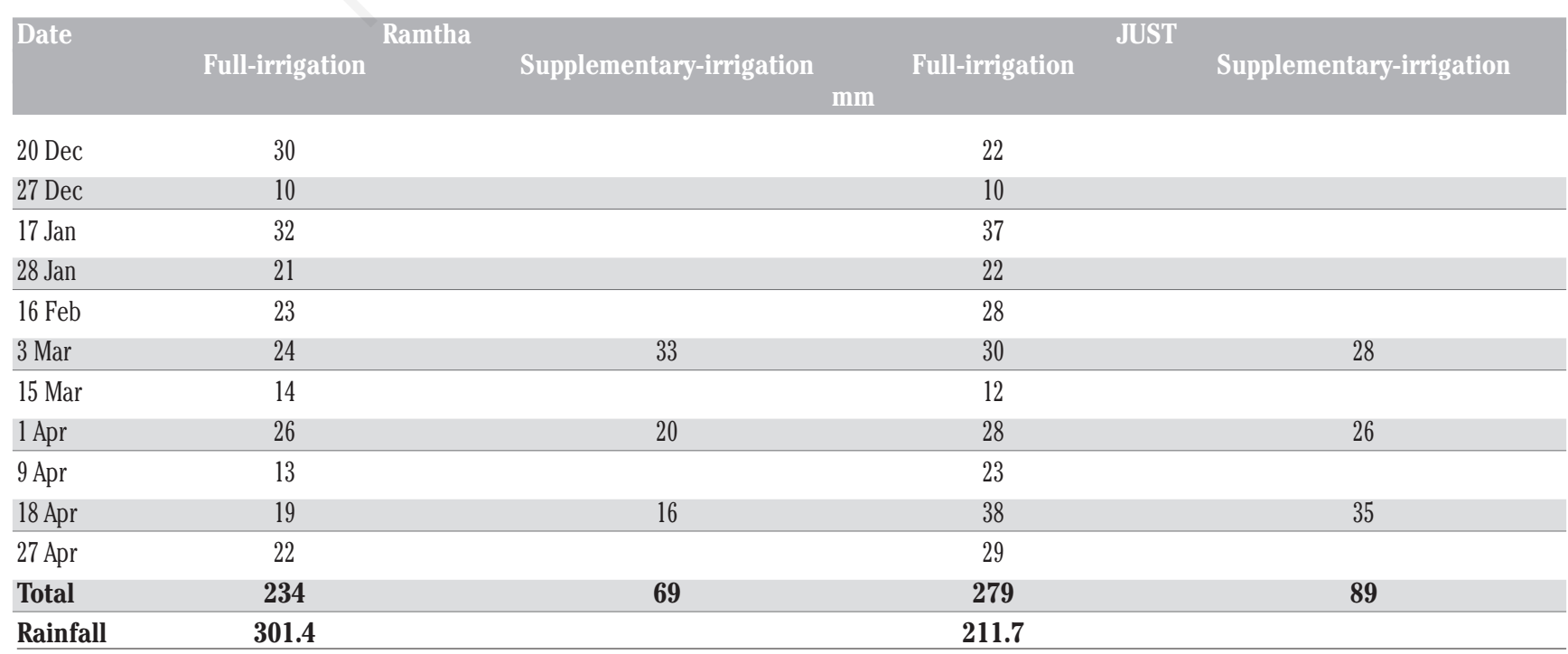


$\mathrm{HNO}_{3}$ and diluted up to $50 \mathrm{ml}$ in a volumetric flask. Zinc (Zn), Cadmium $(\mathrm{Cd})$, and lead $(\mathrm{Pb})$ were determined using Atomic Absorption Spectroscopy. Potassium (K) was measured using the flame photometer.

\section{Experimental design and data analysis}

The dataset was tested according to the basic assumptions of analysis of variance (ANOVA). The normal distribution of the experimental error and the common variance of the experimental error were verified through the Shapiro-Wilk test. Combined ANOVA procedure across different experimental locations was performed according to a split-plot design with four replicates. The main factor was the irrigation treatments and the split factor was the cultivars. ANOVA analysis were performed using MSTAT software (East Lansing, MI) and basic assumptions of analysis of variance was tested using JMP software package, version 8 (SAS Institute Inc., Cary, NC, USA). Means were compared using the Least Significantly Differences (LSD) at $\alpha=0.05$.

\section{Results}

\section{Photosynthetic rate and stomatal resistance}

Mean values of the plant photosynthetic rate of four-barley cultivars exposed to four-irrigation treatments at two locations were shown in Figure 1. Plants exposed to full-irrigation using treated wastewater (FWW), supplementary-irrigation using treated wastewater (SWW) or supplementary-irrigation using fresh water (SFW) had higher photosynthetic rates than those plants grown under rainfed (RF) conditions at all measured dates (16 March, 2 April, 19 April, and 7 May of 2011) (Figure 1A). Plants irrigated with treated wastewater (FWW and SWW) tend to have higher photosynthetic rate than those irrigated with fresh water (SFW). In general, plants grown under full-irrigation using treated wastewater had the highest photosynthetic rate. The difference in photosynthetic rate among cultivars varied with irrigation treatments and locations. ACSAD176 and Rum had higher mean photosynthetic rate than Athroh and Yarmouk on 16 March and 2 April (Figure 1B), especially when plants were grown under FWW (significant
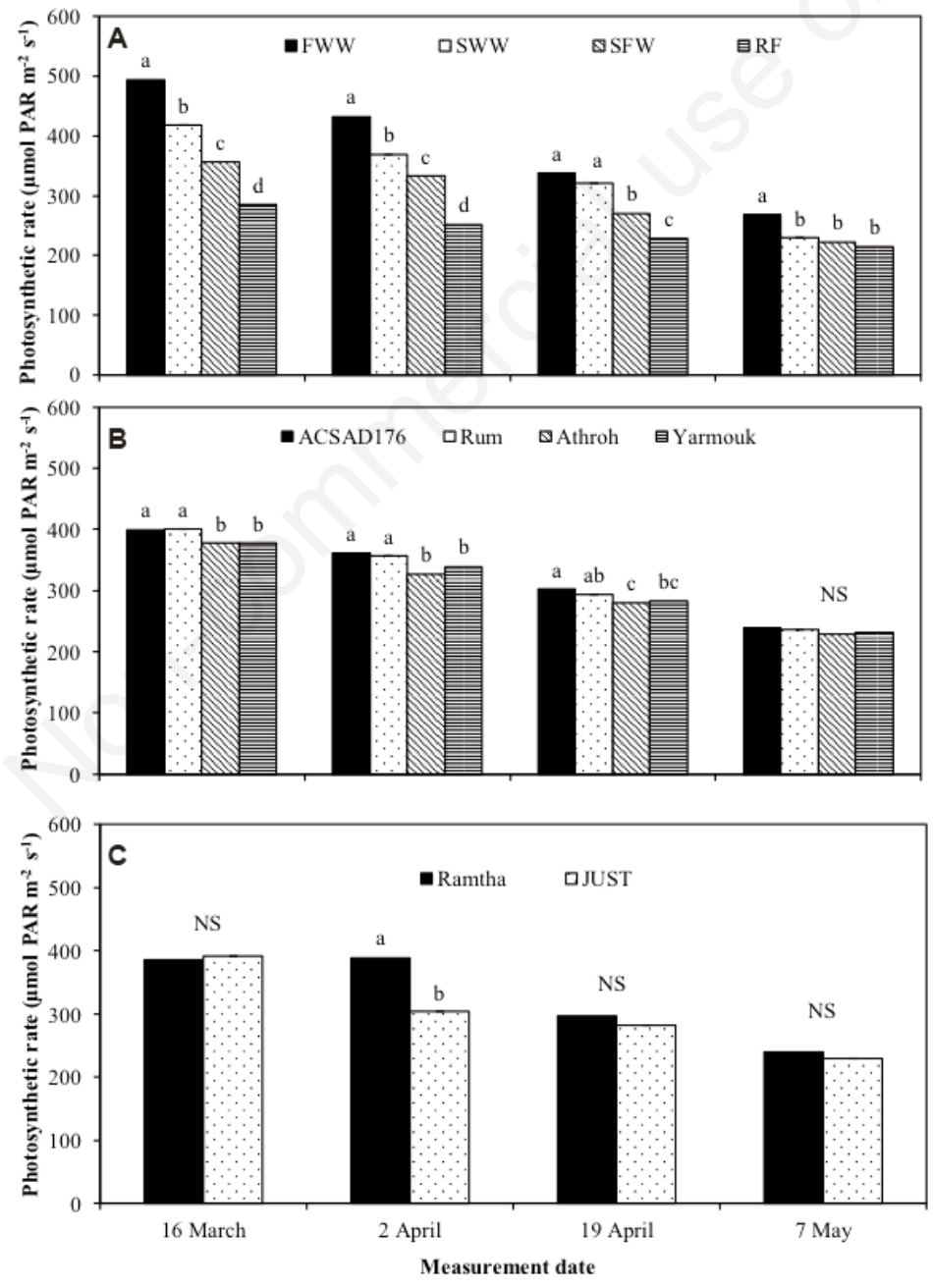

Figure 1. Mean values of photosynthetic rate of barley plants exposed to: A) Four-irrigation treatments (FWW, SWW, SFW, and RF); B) For four cultivars (ACSAD176, Rum, Athroh, and Yarmouk); C) At two locations (Ramtha and JUST). FWW, full-irrigation using treated wastewater; SWW, supplementary-irrigation using treated wastewater; SFW, supplementary-irrigation using fresh water; RF, rainfed. Mean values within measurement date followed by the same letter are not significantly different according to Fisher's Protected Least Significantly Difference ( $\left(\mathrm{LD}_{\alpha=0.05}\right)$. NS indicates non-significant in ANOVA. 
Table 3. F-value and probability (P-value) in analysis of variance table (ANOVA) for photosynthetic rate, stomatal resistance, plant height $(\mathrm{PH})$, spike number plant ${ }^{-1}(\mathrm{SN}), 1000$-seed weight $(\mathrm{SW})$, and grain yield ha ${ }^{-1}(\mathrm{GY})$ of four-barley cultivars exposed to fourirrigation treatments using treated wastewater at two locations (Ramtha and JUST).

\begin{tabular}{|c|c|c|c|c|c|c|c|c|c|c|c|c|c|}
\hline \multirow{2}{*}{ Source } & \multirow[t]{2}{*}{ DF } & \multicolumn{4}{|c|}{ Photosynthetic rate } & \multicolumn{4}{|c|}{ Stomatal resistance } & \multirow[t]{2}{*}{ PH } & \multicolumn{3}{|c|}{ Yield components } \\
\hline & & 16 March & 2 April & 19 April & 7 May & 16 March & 2 April & 19 April & 7 May & & SN & SW & GY \\
\hline Block & 3 & 9.7 & 3.8 & 0.3 & 1.7 & 1.2 & 1.2 & 8.0 & 4.7 & 0.5 & 0.2 & 0.5 & 2.6 \\
\hline Location (L) & 1 & 0.4 & $50.4^{* *}$ & 5.1 & 1.1 & $34.8^{* *}$ & $44.1^{* *}$ & $86.7^{* *}$ & 3.4 & $224.8^{* * *}$ & $42.3^{* *}$ & $96.9 * *$ & $183.8^{* * *}$ \\
\hline Error a & 3 & & & & & & & & & & & & \\
\hline Irrigation (I) & 3 & $151.5^{* * *}$ & $128.5^{* * *}$ & $80.3^{* * *}$ & $10.5^{* * *}$ & $150.3^{* * *}$ & $122.7^{* * *}$ & $13.7^{* * *}$ & $53.1^{* * *}$ & $267.3^{* * *}$ & $5.0^{* *}$ & $20.9^{* * *}$ & $114.3^{* * *}$ \\
\hline I*L & 3 & $3.7^{*}$ & 2.1 & 0.6 & 0.4 & 3.1 & $17.4^{* * *}$ & $10.1^{* * *}$ & $41.3^{* * *}$ & $19.8^{* * *}$ & 1.4 & 2.6 & 0.9 \\
\hline Error b & 18 & & & & & & & & & & & & \\
\hline Cultivar (C) & 3 & $3.2^{*}$ & $9.7^{* * *}$ & $6.5^{* * *}$ & 1.1 & 1.7 & $3.4^{*}$ & 0.6 & $4.4^{* *}$ & $79.0^{* * *}$ & $24.1^{* * *}$ & $11.3^{* * *}$ & $28.6^{* * *}$ \\
\hline $\mathrm{C}^{*} \mathrm{~L}$ & 3 & 1.3 & 1.3 & 0.3 & 0.02 & 2.6 & 2.2 & 0.2 & $3.7^{*}$ & 0.4 & $8.5^{* * *}$ & $2.7^{*}$ & $6.4^{* * *}$ \\
\hline C*I & 9 & $3.0^{* *}$ & 0.7 & 145.8 & 0.05 & 1.1 & 0.7 & 1.1 & $5.8^{* * *}$ & $1.7^{*}$ & 0.1 & 1.0 & $2.4^{*}$ \\
\hline$C^{*} \mathrm{~L}^{*} \mathrm{I}$ & 9 & 0.8 & 0.5 & 91.5 & 0.02 & 0.8 & 1.1 & 1.9 & 1.4 & 2.6 & 0.2 & 0.4 & 0.4 \\
\hline
\end{tabular}

Error c $\quad 72$

Significant at $* \mathrm{P}=0.05 ; * * \mathrm{P}=0.01 ; * * * \mathrm{P}=0.001$.
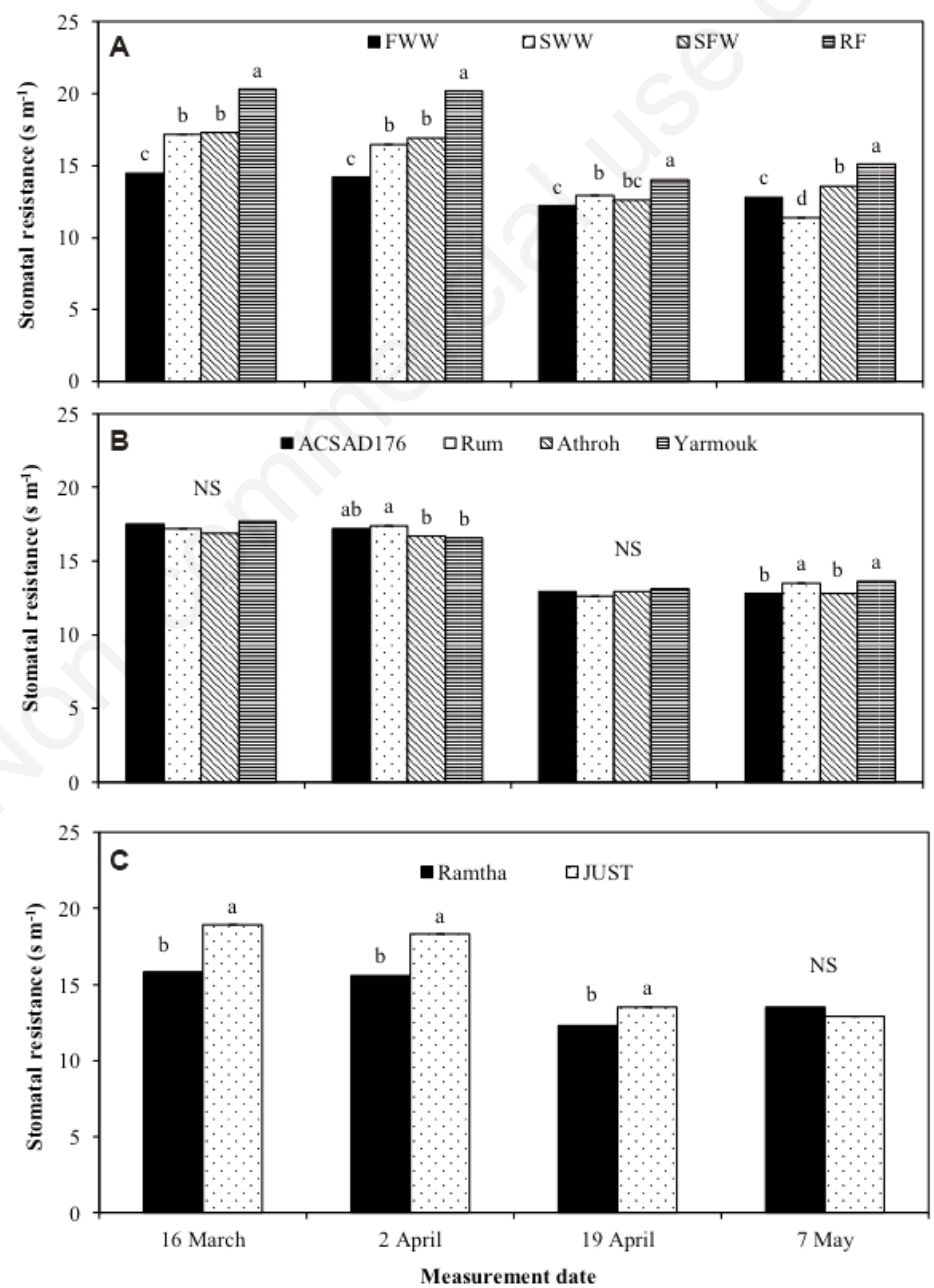

Figure 2. Mean values of stomatal resistance of barley plants exposed to: A) Four-irrigation treatments (FWW, SWW, SFW, and RF); B) For four cultivars (ACSAD176, Rum, Athroh, and Yarmouk); C) At two locations (Ramtha and JUST). FWW, full-irrigation using treated wastewater; SWW, supplementary-irrigation using treated wastewater; SFW, supplementary-irrigation using fresh water; RF, rainfed. Mean values within measurement date followed by the same letter are not significantly different according to Fisher's Protected Least Significantly Difference ( $\left.\mathrm{LSD}_{\alpha=0.05}\right)$. NS indicates non-significant in ANOVA. 
cultivar $\times$ irrigation interaction) (Table 3). On 19 April, ACSAD176 and Rum had higher photosynthetic rate than Athroh. The differences in photosynthetic rate among cultivars were not significant on 7 May. Plants grown under FWW, SWW, or SFW had lower stomatal resistance than those plants grown under RF conditions at both locations at all measured dates (Figure 2).

There were no differences in stomatal resistance among cultivars except for 2 April when ACSAD176 and Rum had significantly higher stomatal resistance than Athroh and Yarmouk.

\section{Plant height and yield components}

At both locations, plants grown under FWW, SWW, or SFW had higher plant height than those grown under RF conditions for all cultivars (Figure 3). ACSAD176 cultivar had the highest plant height, followed by Rum, Athroh, and Yarmouk cultivars. Yarmouk cultivar had the lowest plant height for different irriga- tion treatments and locations.

Irrigation treatments had significant effect on mean values of spike number plant ${ }^{-1}$ and 1000-grain weight (Tables 3 and 4). Plants grown under FWW or SWW had higher spike number plant ${ }^{-1}$ than those grown under RF conditions. There were no significantly differences in spike number plant $^{-1}$ among FWW, SWW, or SFW treatments. Plants grown under FWW had the highest 1000-grain weight, while plants grown under RF conditions had the lowest. The cultivar $\mathrm{x}$ location interaction effect was significant for spike number plant ${ }^{-1}$ and 1000-grain weight (Table 3). ACSAD176, Rum, and Athroh cultivars had lower spike number plant ${ }^{-1}$ than Yarmouk at Ramtha, but the difference was not significant at JUST. ACSAD176, Rum, and Athroh cultivars had higher 1000grain weight than Yarmouk cultivar at Ramtha location. At JUST location, Rum cultivar had the highest 1000-grain weight, while Yarmouk cultivar had the lowest. Plants grown at Ramtha had

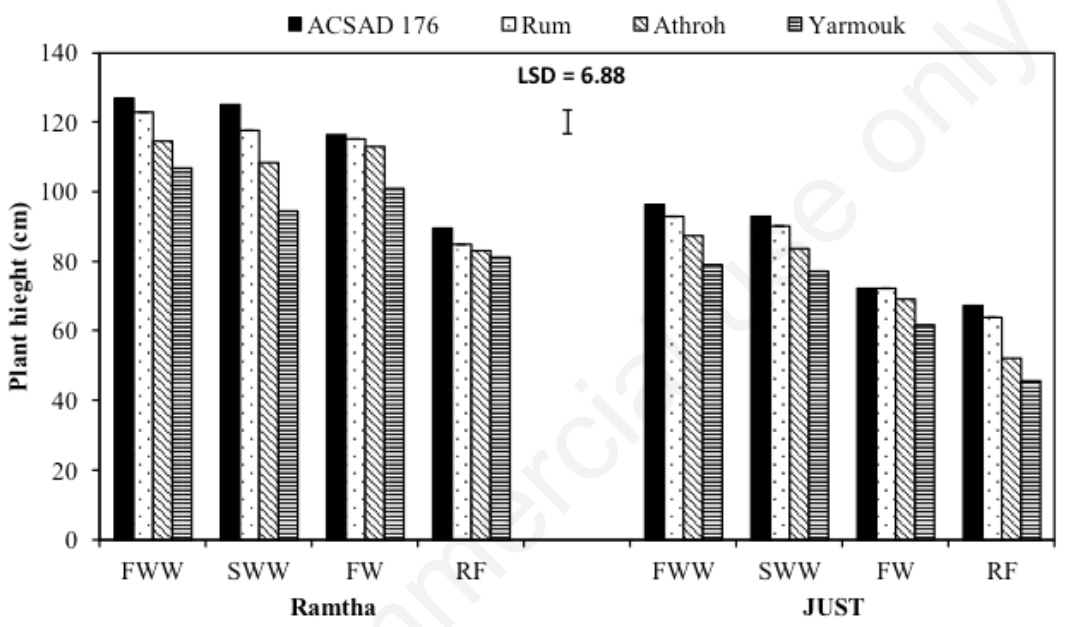

Figure 3. Mean values of plant height of four-barley cultivars (ACSAD176, Rum, Athroh, and Yarmouk) exposed to four-irrigation treatments at two locations (Ramtha and JUST) (location $\times$ irrigation treatment $\times$ cultivar interaction effect). FWW, full-irrigation using treated wastewater; SWW, supplementary-irrigation using treated wastewater; SFW, supplementary-irrigation using fresh water; RF, rainfed. Bars or LSD values indicate the Least Significantly Difference (LSD $\alpha=0.05)$.

Table 4. Spike number plant ${ }^{-1}$ and 1000-grain weight for four-barley cultivars exposed to four-irrigation treatments at two locations (Ramtha and JUST).

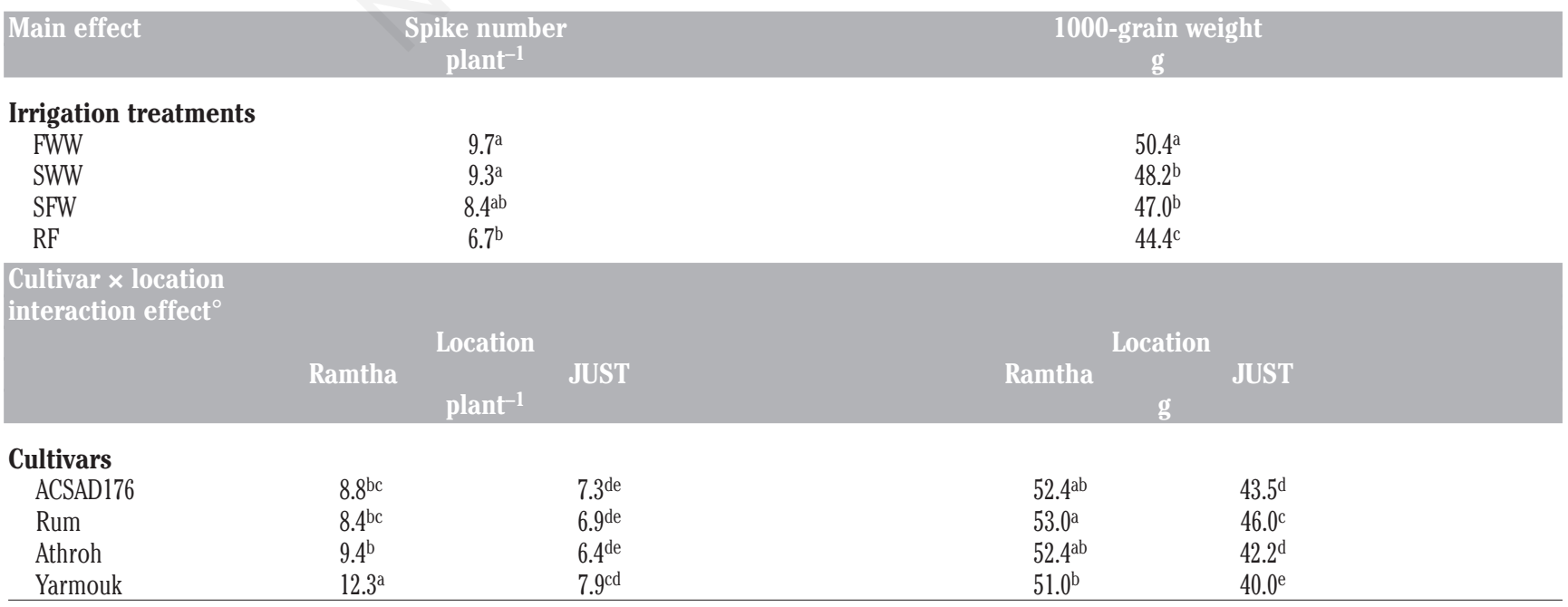

FWW, full-irrigation using treated wastewater; SWW, supplementary-irrigation using treated wastewater; SFW, supplementary-irrigation using fresh water; RF, rainfed. Means within columns followed by the same letters a-care not significantly different according to Fisher's Protected Least Significantly Difference ( $\left.\mathrm{LSD}_{\alpha=0.05}\right)$; ${ }^{\circ}$ Means within columns and rows (for cultivar $\times$ location interaction) followed by the same letter ${ }^{\mathrm{a}-\mathrm{d}}$ are not significantly different according to Fisher's Protected Least Significantly Difference $\left(\mathrm{LSD}_{\alpha=0.05}\right)$. 
higher spike number plant ${ }^{-1}$ and 1000-grain weight than those grown at JUST for all cultivars.

The irrigation $\times$ cultivar interaction effect was significant for grain yield ha ${ }^{-1}$ (Table 3). For ACSAD176 and Rum cultivars, plants grown under FWW had the highest grain yield, followed by plants grown under SWW, SFW, and RF (Table 5). For Athroh and Yarmouk cultivars, plants grown under either FWW or SWW had the highest grain yield, followed by plants grown under SFW and FR. Under irrigation treatments (FWW, SWW, and SFW), Rum cultivar had the highest grain yield. ACSAD176 cultivar had higher grain yield than Athroh and Yarmouk cultivars under the FWW treatment. Under RF conditions, Rum and ACSAD176 cultivars had the highest grain yield, while Athroh and Yarmouk cultivars had the lowest. The cultivar $\times$ location interaction effect was significant for grain yield. At Ramtha location, Rum cultivar had the highest grain yield. At JUST location, Rum cultivar had higher grain yield than Athroh and Yarmouk cultivars, but grain yield of Rum was not different from that of ACSAD176 cultivar.

\section{Soil and grain mineral analysis}

Irrigation treatments using treated wastewater had no significant effect $(\mathrm{P}<0.05)$ on soil physical and chemical properties at Ramtha (Table 6) and JUST (Table 7) locations. At Ramtha location, soil electrical conductivity (EC), concentration of $\mathrm{K}, \mathrm{Zn}, \mathrm{Fe}$, and $\mathrm{Cd}$ were higher in $0-20 \mathrm{~cm}$ soil layer than those in $20-40 \mathrm{~cm}$. At JUST location, concentration of $\mathrm{Na}, \mathrm{P}, \mathrm{K}, \mathrm{Zn}, \mathrm{Cd}$, and $\mathrm{Pb}$ were higher in $0-20 \mathrm{~cm}$ soil layer than $20-40 \mathrm{~cm}$. At both locations, the sodium adsorption ratio (SAR) was lower in $0-20 \mathrm{~cm}$ soil layer than in $20-40 \mathrm{~cm}$. At JUST location, the $\mathrm{pH}$ was lower in $0-20 \mathrm{~cm}$ soil layer than in $20-40 \mathrm{~cm}$. Irrigation treatments increased $\mathrm{P}$ concentration in barley grains compared with rainfed treatment, but did not change concentrations of $\mathrm{K}, \mathrm{Zn}, \mathrm{Cd}$, and $\mathrm{Pb}$ (Table 8).

Table 5. Grain yield of four-barley cultivars exposed to four-irrigation treatments at two locations (Ramtha and JUST).

\begin{tabular}{|c|c|c|c|c|c|}
\hline $\begin{array}{l}\text { Irrigation x cultivar } \\
\text { interaction effect }\end{array}$ & ACSAD176 & Rum & $\begin{array}{l}\text { Grain yield } \\
\text { Cultivar }\end{array}$ & Athroh & Yarmouk \\
\hline & & & $\mathrm{kg} \mathrm{ha}^{-1}$ & & \\
\hline $\begin{array}{l}\text { Irrigation treatments } \\
\text { FWW } \\
\text { SWW } \\
\text { SFW } \\
\text { RF }\end{array}$ & $\begin{array}{l}5140^{\mathrm{b}} \\
4530^{\mathrm{c}} \\
3320^{\mathrm{ef}} \\
2440^{\mathrm{gh}}\end{array}$ & $\begin{array}{l}5960^{\mathrm{a}} \\
5120^{\mathrm{b}} \\
3790^{\mathrm{de}} \\
2510^{\mathrm{gh}}\end{array}$ & & $\begin{array}{l}4180^{\text {cd }} \\
3740^{\text {de }} \\
2930^{\text {fg }} \\
2210^{\mathrm{h}}\end{array}$ & $\begin{array}{l}4510^{\mathrm{c}} \\
4210^{\mathrm{cd}} \\
3060^{\mathrm{f}} \\
2130^{\mathrm{h}}\end{array}$ \\
\hline $\begin{array}{l}\text { Cultivar } \times \text { location } \\
\text { interaction effect }\end{array}$ & & Ramtha & Location & JUST & \\
\hline & & & $\mathrm{kg} \mathrm{ha}^{-1}$ & & \\
\hline $\begin{array}{l}\text { Cultivars } \\
\text { ACSAD176 } \\
\text { Rum } \\
\text { Athroh } \\
\text { Yarmouk } \\
\end{array}$ & & $\begin{array}{l}4520^{\mathrm{b}} \\
5290^{\mathrm{a}} \\
3670^{\mathrm{d}} \\
4050^{\mathrm{c}}\end{array}$ & & $\begin{array}{c}3200^{\text {ef }} \\
3400^{\text {de }} \\
2860^{f} \\
2900^{f}\end{array}$ & \\
\hline
\end{tabular}

FWW, full-irrigation using treated wastewater; SWW, supplementary-irrigation using treated wastewater; SFW, supplementary-irrigation using fresh water; RF, rainfed. a-hMeans within columns and rows (for irrigation $\times$ cultivar interaction) followed by the same letter are not significantly different according to Fisher's Protected Least Significantly Difference (LSD $\alpha=0.05$ ).

Table 6. Soil physical and chemical properties at two depths before and after imposing irrigation treatments on barley plants grown at Ramtha location.

\begin{tabular}{|c|c|c|c|c|c|c|}
\hline \multirow[t]{2}{*}{ Soil parameter } & \multicolumn{2}{|c|}{$\begin{array}{l}\text { Before }^{\circ} \\
\text { Depth }\end{array}$} & \multicolumn{2}{|c|}{$\begin{array}{l}\text { After } \\
\text { Depth }\end{array}$} & \multicolumn{2}{|c|}{ Mean } \\
\hline & $0-20 \mathrm{~cm}$ & $20-40 \mathrm{~cm}$ & $0-20 \mathrm{~cm}$ & $20-40 \mathrm{~cm}$ & $0-20 \mathrm{~cm}$ & $20-40 \mathrm{~cm}$ \\
\hline $\mathrm{pH}$ & 7.7 & 7.8 & 7.8 & 7.8 & $7.8^{\mathrm{a}}$ & $7.9^{\mathrm{a}}$ \\
\hline $\mathrm{EC}(\mathrm{ds} / \mathrm{m})$ & 1.5 & 1.4 & 1.4 & 1.2 & $1.5^{\mathrm{a}}$ & $1.3^{\mathrm{b}}$ \\
\hline $\mathrm{Ca}(\mathrm{mg} / \mathrm{L})$ & 66.3 & 67.1 & 66.7 & 64.3 & $66.5^{\mathrm{a}}$ & $65.7^{\mathrm{a}}$ \\
\hline $\mathrm{Mg}(\mathrm{mg} / \mathrm{L})$ & 30.5 & 29.0 & 29.3 & 29.4 & $29.8^{\mathrm{a}}$ & $29.3^{\mathrm{a}}$ \\
\hline $\mathrm{Na}(\mathrm{mg} / \mathrm{L})$ & 55.8 & 58.6 & 52.9 & 60.2 & $54.3^{\mathrm{a}}$ & $59.5^{\mathrm{a}}$ \\
\hline $\mathrm{Na}(\%)$ & 18.0 & 18.0 & 18.1 & 17.4 & $18.1^{\mathrm{a}}$ & $17.7^{\mathrm{a}}$ \\
\hline SAR & 1.9 & 2.9 & 2.2 & 2.9 & $2.2^{\mathrm{b}}$ & $2.9^{\mathrm{a}}$ \\
\hline $\mathrm{P}(\mathrm{ppm})$ & 18.6 & 18.1 & 19.1 & 18.6 & $18.8^{a}$ & $18.4^{\mathrm{a}}$ \\
\hline $\mathrm{K}(\mathrm{ppm})$ & 741.4 & 689.2 & 751.2 & 695.9 & $746.3^{\mathrm{a}}$ & $692.5^{\mathrm{b}}$ \\
\hline Zn (ppm) & 1.4 & 1.2 & 1.0 & 0.9 & $1.2^{\mathrm{a}}$ & $1.0^{\mathrm{b}}$ \\
\hline $\mathrm{Fe}(\mathrm{ppm})$ & 4.9 & 4.1 & 5.0 & 4.1 & $5.0^{\mathrm{a}}$ & $4.1^{\mathrm{b}}$ \\
\hline Cd (ppm) & 0.1 & 0.1 & 0.1 & 0.1 & $0.1^{\mathrm{a}}$ & $0.1^{\mathrm{b}}$ \\
\hline $\mathrm{Pb}(\mathrm{ppm})$ & 1.6 & 0.9 & 1.1 & 0.9 & $1.4^{\mathrm{a}}$ & $0.9^{\mathrm{a}}$ \\
\hline
\end{tabular}

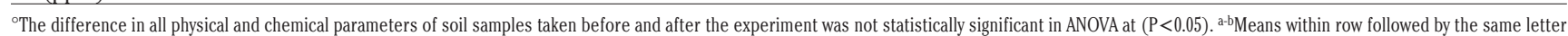
is not significantly different according to Fisher's Protected Least Significantly Difference ( $\operatorname{LSD}_{\alpha=0.05}$ ). 


\section{Discussion}

In the present study, barley plants grown under rainfed conditions suffered from drought stress as measured by the reduction in photosynthetic rate and the increase in stomatal resistance (Figures 1 and 2). Plants grown under irrigation using treated wastewater or fresh water significantly alleviated the negative effect of drought stress on plants photosynthetic rate and stomatal resistance (Figures 1 and 2). Drought stress has been reported to decrease plant photosynthetic rate by increasing stomatal resistance (stomata closure) and decreasing $\mathrm{CO}_{2}$ availability in the leaf intercellular air spaces (Flexas et al., 2004; Ghotbi-Ravandi et al., 2014) or by alternating photosynthetic metabolism (Signarbieux and Feller, 2011). Although stomata closure is considered as a first step to adapt to drought by maintaining cell turgor to continue plant metabolism (Lipiec et al., 2013), stomata closure under drought stress can lead to reduced yield (Blum, 2009). In the present study, irrigation treatments increased plant height compared with rainfed condition (Figure 3). Under rainfed condition, plants received low amount of rainfall (59.9 and $34.2 \mathrm{~mm}$ ) during the reproductive growth stage (April-May) at Ramtha and JUST, respectively (Table 1). Plants are most susceptible to drought stress at the reproductive-growth stage where drought stress can delay or inhibit flowering and result in reduction in grain yield of many crop species (Saini and Westgate, 1999; Nguyen and Sutton, 2009; Praba et al., 2009; Alqudah et al., 2011).
Barley plants grown under irrigation using treated wastewater had higher grain yield ha $\mathrm{h}^{-1}$ and yield components as measured by spike number plant ${ }^{-1}$ and 1000-grain weight compared with plants grown under rainfed conditions (Table 4 and 5). The full-irrigation treatment using treated wastewater resulted in the highest grain yield for ACSAD176 and Rum cultivars, while the full-irrigation or supplementary-irrigation treatments resulted in the highest grain yield for Athroh and Yarmouk (Table 5). The use of treated wastewater in irrigation increased growth and yield of many crop species (Al-Nakshabandi et al., 1997; Al-Lahham et al., 2003; Mohammad and Mazahreh, 2003; Mohammad and Ayadi, 2004). In the present study, the results suggest that ACSAD176 and Rum responded more to the increase in irrigation frequency using treated wastewater (full-irrigation, FWW) by increasing their grain yield compared with the supplementary-irrigation using treated wastewater (Supplementary-irrigation, SWW) (Table 5). With regard of Athroh and Yarmouk, the increase in the frequency of irrigation using treated wastewater (FWW) did not significantly improved the grain yield compared with the supplementary-irrigation treatment (SWW) (Table 5). Full-irrigation using treated wastewater resulted in a further increase in plant height, which can lead to plant lodging and reduction in yield when plants receive more rainfall late in the season (Figure 3). Although irrigation using treated wastewater did not change the soil physical and chemical properties (Table 6 and 7), more frequent irrigation may result in the accumulation of heavy metals in soil in the long-term.

Table 7. Soil physical and chemical properties at two depths before and after imposing irrigation treatments on barley plants grown at JUST location.

\begin{tabular}{|c|c|c|c|c|c|c|}
\hline \multirow[t]{2}{*}{ Soil parameter } & \multicolumn{2}{|c|}{$\begin{array}{c}\text { Before }^{\circ} \\
\text { Depth }\end{array}$} & \multicolumn{2}{|c|}{$\begin{array}{l}\text { After } \\
\text { Depth }\end{array}$} & \multicolumn{2}{|c|}{ Mean } \\
\hline & $0-20 \mathrm{~cm}$ & $20-40 \mathrm{~cm}$ & $0-20 \mathrm{~cm}$ & $20-40 \mathrm{~cm}$ & $0-20 \mathrm{~cm}$ & $20-40 \mathrm{~cm}$ \\
\hline $\mathrm{pH}$ & 7.8 & 7.8 & 7.7 & 7.8 & $7.8^{b}$ & $7.8^{\mathrm{a}}$ \\
\hline $\mathrm{EC}(\mathrm{ds} / \mathrm{m})$ & 1.9 & 1.6 & 1.6 & 1.7 & $1.8^{\mathrm{a}}$ & $1.6^{\mathrm{a}}$ \\
\hline $\mathrm{Ca}(\mathrm{mg} / \mathrm{L})$ & 72.5 & 72.9 & 99.8 & 87.6 & $86.2^{\mathrm{a}}$ & $80.4^{\mathrm{a}}$ \\
\hline $\mathrm{Mg}(\mathrm{mg} / \mathrm{L})$ & 46.3 & 44.4 & 46.1 & 43.5 & $46.2^{\mathrm{a}}$ & $43.9^{\mathrm{a}}$ \\
\hline $\mathrm{Na}(\mathrm{mg} / \mathrm{L})$ & 55.4 & 49.2 & 55.9 & 47.4 & $55.6^{\mathrm{a}}$ & $48.1^{\mathrm{a}}$ \\
\hline $\mathrm{Na}(\%)$ & 19.2 & 17.3 & 17.6 & 16.5 & $18.4^{\mathrm{a}}$ & $16.9^{\mathrm{b}}$ \\
\hline SAR & 1.4 & 2.1 & 1.2 & 1.9 & $1.3^{b}$ & $2.0^{\mathrm{a}}$ \\
\hline $\mathrm{P}(\mathrm{ppm})$ & 17.8 & 15.9 & 17.1 & 15.5 & $17.4^{\mathrm{a}}$ & $15.7^{\mathrm{b}}$ \\
\hline $\mathrm{K}(\mathrm{ppm})$ & 731.2 & 657.4 & 791.9 & 712.3 & $761.6^{\mathrm{a}}$ & $684.9^{b}$ \\
\hline Zn (ppm) & 0.9 & 0.7 & 1.0 & 0.8 & $0.9^{\mathrm{a}}$ & $0.8^{b}$ \\
\hline $\mathrm{Fe}(\mathrm{ppm})$ & 4.1 & 3.8 & 3.9 & 3.6 & $3.9^{\mathrm{a}}$ & $3.7^{\mathrm{a}}$ \\
\hline Cd (ppm) & 0.1 & 0.1 & 0.1 & 0.1 & $0.1^{\mathrm{a}}$ & $0.1^{\mathrm{b}}$ \\
\hline$\underline{\mathrm{Pb}(\mathrm{ppm})}$ & 1.0 & 0.9 & 1.2 & 0.9 & $1.1^{\mathrm{a}}$ & $0.9^{\mathrm{b}}$ \\
\hline
\end{tabular}

${ }^{\circ}$ The difference in all physical and chemical parameters of soil samples taken before and after the experiment was not statistically significant at $(\mathrm{P}<0.05)$; $\mathrm{a}-\mathrm{b}$ Means within row followed by the same letter is not significantly different according to Fisher's Protected Least Significantly Difference $\left(\operatorname{LSD}_{\alpha=0.05}\right)$.

Table 8. Mean ( $\mathrm{n}=32)$ concentrations of $\mathrm{P}, \mathrm{K}, \mathrm{Zn}, \mathrm{Cd}$, and $\mathrm{Pb}$ (on a dry-weight basis) in barley grains harvested from plants exposed to four-irrigation treatments averaged over four cultivars and two locations.

\begin{tabular}{|c|c|c|c|c|c|}
\hline Treatments & $\mathbf{P}$ & $\mathbf{K}$ & $\mathrm{Zn}$ & $\begin{array}{c}\mathrm{Cd} \\
\mu \mathrm{g}^{-1}\end{array}$ & $\mathrm{~Pb}$ \\
\hline FWW & $0.22^{\mathrm{ab}}$ & $0.54^{\mathrm{a}}$ & $19.9^{\mathrm{a}}$ & $0.57^{\mathrm{a}}$ & $11.1^{\mathrm{a}}$ \\
\hline SWW & $0.26^{\mathrm{a}}$ & $0.54^{\mathrm{a}}$ & $21.5^{\mathrm{a}}$ & $1.08^{a}$ & $9.7^{\mathrm{a}}$ \\
\hline FW & $0.24^{\mathrm{a}}$ & $0.49^{\mathrm{a}}$ & $20.8^{\mathrm{a}}$ & $0.60^{\mathrm{a}}$ & $11.9^{\mathrm{a}}$ \\
\hline $\mathrm{RF}$ & $0.17^{\mathrm{b}}$ & $0.46^{\mathrm{a}}$ & $21.3^{\mathrm{a}}$ & $0.64^{\mathrm{a}}$ & $10.9^{\mathrm{a}}$ \\
\hline
\end{tabular}

FWW, full-irrigation using treated wastewater; SWW, supplementary-irrigation using treated wastewater; SFW, supplementary-irrigation using fresh water; RF, rainfed. ${ }^{a-b}$ Means within columns followed by the same letter is not significantly different according to Fisher's Protected Least Significantly Difference (LSD $\alpha=0.05)$. 
Accumulation of heavy metals such as lead $(\mathrm{Pb})$ and cadmium (Cd) in barley plants increased when plants were grown in a site irrigated with treated wastewater for 10 years compared with that irrigated with wastewater for 2 years (Rusan et al., 2007). It is recommended to carefully manage the use of treated wastewater for irrigation by decreasing the irrigation frequency (Mañas et al., 2009) and by applying wastewater at a rate that does not exceed the threshold level of heavy metals for crop production (Pesco, 1992). In addition, the efficient use and conservation of agricultural water by producing more with the existing water resources and with minimum deterioration and contamination of land is essential strategy for sustainable management of available water resources (Pereira et al., 2002; Qadir et al., 2003). In the present study, the supplementary-irrigation treatment using treated wastewater improved the grain yield of barley and can be a better choice for conserving water, reducing plant lodging risk at the end of the season, and possibly reducing the accumulation of heavy metals in soil at the long term. The grain yield of barely grown under supplementary-irrigation using treated wastewater (SWW) was higher than those grown under supplementary-irrigation using fresh water (SFW) for all cultivars averaged across two locations (Table 5). Our results were inconsistent with finding of Chaganti et al. (2020) who reported that treated wastewater did not have an effect on sorghum biomass yield compared with fresh water, but changed biomass quality due to rising of soil salinity and sodicity. The SWW improved plant growth as measured by plant height at the drier location (JUST) more than that at the wetter location (Ramtha) compared with the SFW treatment. Other researchers found that irrigating plants with treated wastewater increased plant growth as measured by plant fresh and dry weight, and height in barley (Rusan et al., 2007) and lettuce (Lactuca sativa L.) (Castro et al., 2013). In the present study, the results suggest that reusing treated wastewater as a supplementary irrigation gave an advantage in grain yield over supplementary irrigation using fresh water. Irrigation using treated wastewater can be a source of essential nutrients for better plant growth (Rusan et al., 2007) and higher grain yield.

The response of barley cultivars to different irrigation treatments using either treated wastewater or fresh water showed that Rum had a higher grain yield than other cultivars, especially under irrigation or wetter location (Table 5). These results were consistent with the findings of Samarah et al. (2009), who reported that the traditional cultivar (Rum) had either similar or higher grain yield than other cultivars when plants were grown under three levels of late-drought stress in glasshouse- and field-experiments. The higher yield of Rum cultivar was related to higher spike number plant $^{-1}$ and grain number spike ${ }^{-1}$, but not days to heading or grain filling duration (Samarah et al., 2009). In the current and previous study (Samarah et al., 2009), Yarmouk cultivar (the only two-row barley cultivar) had the lowest grain yield. All cultivars had higher plant height and produced higher grain yield at Ramtha (wetter location) than at JUST (drier location) (Table 5). The grain yield at JUST location was reduced by 29, 35, 28, and $22 \%$ for ACSAD176, Rum, Athroh, and Yarmouk cultivars compared to Ramtha location, respectively. Although Rum cultivar had the greatest reduction in grain yield at the drier location (JUST) compared to wetter location (Ramtha), the grain yield of Rum at JUST was higher than that of other cultivars.

Irrigation of barley plants using treated wastewater had no significant effect $(\mathrm{P}<0.05)$ on the soil physical and chemical properties and the accumulation of mineral nutrients and heavy metals in barley grains, except for an increase in $\mathrm{P}$ (Tables 6-8). However, the concentrations of heavy metals $(\mathrm{Cd}$ and $\mathrm{Pb})$ in barley grains harvested from all treatments including rainfed were high (0.56-
1.08 and 9.7-11.9 ppm, respectively), exceeding the maximum limit set by the Joint Food Agriculture Organization/World Health Organization (FAO/WHO) (0.1 and $0.2 \mathrm{ppm}$, respectively) (Table 8). The concentrations of $\mathrm{Cd}$ and $\mathrm{Pb}$ in soil before and after sowing were $0.10-0.12$ and $0.88-1.38 \mu \mathrm{g} \mathrm{g}^{-1}$ at Ramtha location and $0.11-$ 0.13 and $0.91-1.12 \mu \mathrm{g} \mathrm{g}^{-1}$ at JUST location, respectively (Table 6 and 7), which were not very high, but far below the threshold values reported in the international literature (Ewers, 1991; Pendias and Pendias, 1992). The concentration of K, Zn, Fe, Na, Cd, and $\mathrm{Pb}$ were significantly $(\mathrm{P}<0.05)$ higher in the upper layer of soil $(0$ $20 \mathrm{~cm}$ ) than the lower layer $(20-40 \mathrm{~cm})$. Rusan et al. (2007) found that irrigation using wastewater had no significant effect on soil heavy metals $(\mathrm{Pb}$ and $\mathrm{Cd})$ regardless of the duration of irrigation ( 2,5 , or 10 years); however, plant $\mathrm{Pb}$ and $\mathrm{Cd}$ increased with the increase in the duration of wastewater irrigation. Irrigation of eggplant using treated wastewater resulted in a slight increase in heavy metals accumulation in soil, but nutrient and heavy metal concentration in plants did not exceed the normal limit for crops (AlNakshabandi et al., 1997). Irrigation with treated wastewater increased the accumulation of heavy metals such as $\mathrm{Cd}, \mathrm{Ni}, \mathrm{Cu}$, $\mathrm{Zn}$, and $\mathrm{Pb}$ in soil compared with the control, with only $\mathrm{Cd}$ exceeding the permissible limit (Rezapour et al., 2019). The use of municipal treated wastewater for irrigation resulted in accumulation of heavy metals in soil ( $\mathrm{Zn}$ and $\mathrm{Cd})$ and edible parts $(\mathrm{Ni}, \mathrm{Cd}$, $\mathrm{Pb}$, and $\mathrm{Co}$ ) of Brassica oleracea (Kalavrouziotis et al., 2008). The concentration of the $\mathrm{Zn}, \mathrm{Cd}$, and $\mathrm{Pb}$ is wheat grains harvested from plants grown in sites irrigated with treated wastewater were 3.2, 0.52 , and 0.31, respectively (Rezapour et al., 2019). In the present study, the high concentration of $\mathrm{Cd}$ and $\mathrm{Pb}$ in harvested barley grains from all treatments including rainfed plots might be due to factors other than the use of treated wastewater. Similarly, other researchers have reported an elevated of $\mathrm{Cd}$ and $\mathrm{Pb}$ in olive leaves grown in Jordan, due to factors other than the use of treated wastewater (Boufaroua et al., 2013). Other researchers reported that the high concentrations of heavy metals in vegetable crops might be related to the high concentrations of these metals in the polluted air with industrial activities (Ali and Al-Qahtani, 2012). The high $\mathrm{Pb}$ in barley grain might also be due to atmospheric deposition or surface contamination (Zhao et al., 2004). Other sources of $\mathrm{Cd}$ and $\mathrm{Pb}$ contaminations to soil and plant tissues in Jordan could be from the long-term use of P fertilisers, pesticides, and treated wastewater (Ghrefat et al., 2011; AlKhader and Rayyan, 2014; AlKhader, 2015). So, monitoring heavy metals in crops grown in this region is highly needed to understand the cause of heavy metal accumulation in barley grains. The reuse of treated wastewater is highly practiced in Jordan and other developing countries and its impact on accumulation of heavy metals in soil and grains needs serious action to prevent their risk on human health (Bazza, 2003).

\section{Conclusions}

Full- or supplementary-irrigation using treated wastewater reduced stomatal resistance and increased photosynthetic rate, and grain yield and yield components of four-barley cultivars compared with rainfed conditions. Supplementary-irrigation using treated wastewater resulted in higher grain yield than supplementary-irrigation using fresh water. Rum cultivar had the highest grain yield among cultivars under irrigation. Under rainfed conditions, Rum and ACSAD176 cultivars had higher grain yield than Athroh and Yarmouk cultivars. The results suggest that supple- 
mentary-irrigation using treated wastewater is the best treatment to conserve water and improve grain yield of barley. Irrigation using treated wastewater did not change the concentration of heavy metals in soil and barley grains. Harvested barley gains from all treatments including rainfed had an elevated level of $\mathrm{Cd}$ and $\mathrm{Pb}$ and needs further study to be explained.

\section{Highlights}

- Full- or supplementary-irrigation using treated wastewater increased photosynthetic rate and grain yield of barley compared with rainfed.

- Supplementary-irrigation using treated wastewater produced higher grain yield than supplementary-irrigation using fresh water.

- Rum cultivar had the highest grain yield among cultivars grown under irrigation.

- Under rainfed conditions, Rum and ACSAD176 cultivars had the highest grain yield.

- Irrigation using treated wastewater did not change the concentration of heavy metals in soil and barley grains.

\section{References}

Abu-Sharar TM, Battikhi AM, 2002. Water resources management under competitive sectoral demand a case study from Jordan. Water Int. 27:364-78.

Al-Hadidi LM, 2009. Treatment and reuse of wastewater using surface and subsurface wetlands. University of Jordan, Amman.

Al-Karaki GN, 2011. Utilization of treated sewage wastewater for green forage production in a hydroponic system. Emirates J. Food Agr. 23:80.

Al-Lahham O, El Assi NM, Fayyad M, 2003. Impact of treated wastewater irrigation on quality attributes and contamination of tomato fruit. Agric. Water Manage. 61:51-62.

Al-Nakshabandi GA, Saqqar MM, Shatanawi MR, Fayyad M, AlHorani H, 1997. Some environmental problems associated with the use of treated wastewater for irrigation in Jordan. Agric. Water Manage. 34:81-94.

Alderfasi AA, 2009. Agronomic and economic impacts of reuse secondary treated wastewater in irrigation under arid and semi-arid regions. World J. Agric. Sci. 5:369-74.

Ali MHH, Al-Qahtani KM, 2012. Assessment of some heavy metals in vegetables, cereals and fruits in Saudi Arabian markets. Egyptian J. Aquat. Res. 38:31-7.

Alikhasi M, Kouchakzadeh M, Baniani E, 2012. The effect of treated municipal wastewater irrigation in non-agricultural soil on cotton plant. J. Agric. Sci. Tech. 14:1357-64.

AlKhader A, 2015. The impact of phosphorus fertilisers on heavy metals content of soils and vegetables grown on selected farms in Jordan. Agrotechnol 4:2.

AlKhader AM, Rayyan AMA, 2014. Effects of phosphorus fertiliser type and rate on plant growth and heavy metal content in lettuce (Lactuca sativa 1.) grown on calcareous soil. Jordan J. Agric. Sci. 10.

Alqudah AM, Samarah NH, Mullen RE, 2011. Drought stress effect on crop pollination, seed set, yield and quality. In: Alternative Farming Systems, Biotechnology, Drought Stress and Ecological Fertilisation. Springer, Berlun, Germany, p 193-213.

APHA, 1995. Standard methods for the examination of water and wastewater. APHA. AWWA and WPCF, ninetieth ed., Washington DC, USA.

Bazza M, 2003. Wastewater recycling and reuse in the Near East
Region: experience and issues. Water Sci. Technol. Water Supply 3:33-50.

Blum A, 2009. Effective use of water (EUW) and not water-use efficiency (WUE) is the target of crop yield improvement under drought stress. Field Crops Res. 112:119-23.

Boufaroua M, Albalawneh A, Oweis T, 2013. Assessing the efficiency of grey-water reuse at household level and its suitability for sustainable rural and human development. Curr. J. App. Sci. Tech. 3:962-72.

Bouwer H, 2000. Integrated water management: emerging issues and challenges. Agric. Water Manage. 45:217-28.

Castro E, Mañas P, De Las Heras J, 2013. Effects of wastewater irrigation in soil properties and horticultural crop (Lactuca sativa L.). J. Plant Nutr. 36:1659-77.

Chaganti VN, Ganjegunte G, Niu G, Ulery A, Flynn R, Enciso JM, Meki MN, Kiniry JR, 2020. Effects of treated urban wastewater irrigation on bioenergy sorghum and soil quality. Agric. Water Manage. 228:105894.

Chen Y, Wang C, Wang Z, 2005. Residues and source identification of persistent organic pollutants in farmland soils irrigated by effluents from biological treatment plants. Environ. Int. 31:778-83.

da Fonseca AF, Melfi AJ, Montes CR, 2005. Maize growth and changes in soil fertility after irrigation with treated sewage effluent. I. Plant dry matter yield and soil nitrogen and phosphorus availability. Commun. Soil Sci. Plant Anal. 36:1965-81.

Dery JL, Rock CM, Goldstein RR, Onumajuru C, Brassill N, Zozaya S, Suri MR, 2019. Understanding grower perceptions and attitudes on the use of nontraditional water sources, including reclaimed or recycled water, in the semi-arid Southwest United States. Environ. Res. 170:500-9.

Erfani AA, Haghnia GH, Alizadeh A, 2001. Effect of irrigation by treated wastewater on the yield and quality of tomato. Agric. Sci. Tech. 15:65-70.

Etchebarne F, Aveni P, Escudier J-L, Ojeda H, 2019. Reuse of treated wastewater in viticulture: Can it be an alternative source of nutrient-rich water? In: BIO Web of Conferences. EDP Sciences, p. 01009.

Ewers U, 1991. Standards, guidelines and legislative regulations concerning metals and their compounds. Metals and their compounds in the environment: 760-710.

Flexas J, Bota J, Loreto F, Cornic G, Sharkey TD, 2004. Diffusive and metabolic limitations to photosynthesis under drought and salinity in $\mathrm{C}_{3}$ plants. Plant Biol. (Stuttg.) 6:269-79.

Foth HD, 1978. Fundamentals of Soil Science. John Wiley \& Sons, New York, USA.

Ghotbi-Ravandi AA, Shahbazi M, Shariati M, Mulo P, 2014. Effects of mild and severe drought stress on photosynthetic efficiency in tolerant and susceptible barley (Hordeum vulgare L.) genotypes. J. Agron. Crop Sci. 200:403-15.

Ghrefat HA, Yusuf N, Jamarh A, Nazzal J, 2011. Fractionation and risk assessment of heavy metals in soil samples collected along Zerqa River, Jordan. Environ. Earth Sci. 66:199-208.

Jahany M, Rezapour S, 2020. Assessment of the quality indices of soils irrigated with treated wastewater in a calcareous semi-arid environment. Ecol. Indicators 109:105800.

Kalavrouziotis I, Robolas P, Koukoulakis P, Papadopoulos A, 2008. Effects of municipal reclaimed wastewater on the macro-and micro-elements status of soil and of Brassica oleracea var. Italica, and B. oleracea var. Gemmifera. Agric. Water Manage. 95:419-26.

Kalavrouziotis IK, Koukoulakis PH, 2012. Soil pollution under the effect of treated municipal wastewater. Environ. Monit. Assess. 184:6297-6305.

Khan S, Cao Q, Zheng YM, Huang YZ, Zhu YG, 2008. Health risks of 
heavy metals in contaminated soils and food crops irrigated with wastewater in Beijing, China. Environ. Pollut. 152:686-92.

Khanpae M, Karami E, Maleksaeidi H, Keshavarz M, 2020. Farmers' attitude towards using treated wastewater for irrigation: The question of sustainability. J. Clean. Prod. 243:118541.

Khattari S, Jamjoum K, 1988. Concentrations of nutrients and some heavy metals in soil and sweet corn irrigated by treated wastewater. Dirasat 15:29-44.

Kiziloglu FM, Turan M, Sahin U, Kuslu Y, Dursun A, 2008. Effects of untreated and treated wastewater irrigation on some chemical properties of cauliflower (Brassica olerecea L. var. botrytis) and red cabbage (Brassica olerecea L. var. rubra) grown on calcareous soil in Turkey. Agric. Water Manage. 95:716-24.

Lipiec J, Doussan C, Nosalewicz A, Kondracka K, 2013. Effect of drought and heat stresses on plant growth and yield: a review. Int. Agrophys. p 463.

Mañas P, Castro E, de las Heras J, 2009. Irrigation with treated wastewater: Effects on soil, lettuce (Lactuca sativa L.) crop and dynamics of microorganisms. J. Environ. Sci. Health, Pt. A: Environ. Sci. Eng. Toxic Hazard. Subst. Control 44:1261-73.

McKeague J, 1978. Manual on soil sampling and methods of analysis. Canadian Society of Soil Science, Ottawa, Canada.

McLean EO, 1982. Soil pH and lime requirement. In: A.L. Page (Ed.), Methods of soil analysis. Part 2. Chemical and microbiological properties. American Society of Agronomy, Madison, WI, USA, p. 199-224.

Meerbach D, Abdoh F, Itleib H, Hind M, 2005. Agricultural reuse of reclaimed water from the Hebron Regional Wastewater Treatment Plant: feasibility, progress and challenges. Al-Bireh Municipality, Ministry of Agriculture, Palestinian Water Authority.

Mohammad MJ, Ayadi M, 2004. Forage yield and nutrient uptake as influenced by secondary treated wastewater. J. Plant Nutr. 27:351-65.

Mohammad MJ, Mazahreh N, 2003. Changes in soil fertility parameters in response to irrigation of forage crops with secondary treated wastewater. Commun. Soil Sci. Plant Anal. 34:1281-94.

Murtaza G, Zia-ur-Rehman M, Rashid I, Qadir M, 2019. Use of Poorquality Water for Agricultural Production. In: Research Developments in Saline Agriculture. Springer, Berlin, Germany, p. 769-783.

Nguyen GN, Sutton BG, 2009. Water deficit reduced fertility of young microspores resulting in a decline of viable mature pollen and grain set in rice. J. Agron. Crop Sci. 195:11-8.

Olsen SR, 1954. Estimation of available phosphorus in soils by extraction with sodium bicarbonate. U.S. Department of Agriculture C, USA.

Pandey R, Saxena C, 2020. Drip Irrigation with Marginal Quality Land and Waters. Sustain. Irrig. Agricult. [In press].

Pedrero F, Kalavrouziotis I, Alarcón JJ, Koukoulakis P, Asano T, 2010. Use of treated municipal wastewater in irrigated agriculture Review of some practices in Spain and Greece. Agric. Water Manage. 97:1233-41.

Pendias A, Pendias H, 1992. Elements of group VIII. Trace elements in soils and plants:271-276.

Pereira LS, Oweis T, Zairi A, 2002. Irrigation management under water scarcity. Agric. Water Manage. 57:175-206.

Pesco MB, 1992. Wastewater treatment and use in agriculture. Food and Agriculture Organization, Rome, Italy.

Praba ML, Cairns JE, Babu RC, Lafitte HR, 2009. Identification of physiological traits underlying cultivar differences in drought tolerance in rice and wheat. J. Agron. Crop Sci. 195:30-46.

Qadir M, Bahri A, Sato T, Al-Karadsheh E, 2010. Wastewater production, treatment, and irrigation in Middle East and North Africa. Irrig. Drain. Syst. 24:37-51.

Qadir M, Boers TM, Schubert S, Ghafoor A, Murtaza G, 2003. Agricultural water management in water-starved countries: challenges and opportunities. Agric. Water Manage. 62:165-85.

Rahimi A, Rezaei S, Nouri H, Aghashiri A, 2012. Effects of municipal wastewater and zinc fertiliser on yield and yield components of wheat (Triticum aestivum L.) in the Yasouj region of Iran. Int. J. Agric. Sci. 2:313-9.

Rezapour S, Atashpaz B, Moghaddam SS, Damalas CA, 2019. Heavy metal bioavailability and accumulation in winter wheat (Triticum aestivum L.) irrigated with treated wastewater in calcareous soils. Sci. Total Environ. 656:261-9.

Rijsberman FR, 2006. Water scarcity: Fact or fiction? Agric. Water Manage. 80:5-22.

Rusan MJM, Hinnawi S, Rousan L, 2007. Long term effect of wastewater irrigation of forage crops on soil and plant quality parameters. Desalination 215:143-52.

Sabagh AE, Hossain A, Islam MS, Barutcular C, Hussain S, Hasanuzzaman M, Akram T, Mubeen M, Nasim W, Fahad S, 2019. Drought and salinity stresses in barley: Consequences and mitigation strategies. Australian J. Crop Sci. 13:810.

Saini HS, Westgate ME, 1999. Reproductive development in grain crops during drought. In: L.S. Donald (Ed.), Advances in Agronomy. Academic Press, p 59-96.

Sakellariou-Makrantonaki M, Papalexis D, Nakos N, Kalavrouziotis I, 2007. Effect of modern irrigation methods on growth and energy production of sweet sorghum (var. Keller) on a dry year in Central Greece. Agric. Water Manage. 90:181-9.

Samarah N, Alqudah A, Amayreh J, McAndrews G, 2009. The effect of late-terminal drought stress on yield components of four barley cultivars. J. Agron. Crop Sci. 195:427-41.

Scott CA, El-Naser H, Hagan RE, Hijazi A, 2003. Facing water scarcity in Jordan. Water Int. 28:209-16.

Signarbieux C, Feller U, 2011. Non-stomatal limitations of photosynthesis in grassland species under artificial drought in the field. Environ. Exp. Bot. 71:192-7.

Tabari M, Salehi A, 2009. Long-term impact of municipal sewage irrigation on treated soil and black locust trees in a semi-arid suburban area of Iran. J. Environ. Sci. 21:1438-45.

UNESCO, 1979. Map of the world distribution of arid regions: Explanatory note: UNESCO, Paris, France, MAB Technical Note No. 17, 54 pp.

Wang J-F, Wang G-X, Wanyan H, 2007. Treated wastewater irrigation effect on soil, crop and environment: Wastewater recycling in the loess area of China. J. Environ. Sci. 19:1093-9.

Zavadil J, 2009. The effect of municipal wastewater irrigation on the yield and quality of vegetables and crops. Soil Water Res. 4:91103.

Zhang Y, Shen Y, 2019. Wastewater irrigation: past, present, and future. WIREs Water 6:e1234.

Zhao FJ, Adams ML, Dumont C, McGrath SP, Chaudri AM, Nicholson FA, Chambers BJ, Sinclair AH, 2004. Factors affecting the concentrations of lead in British wheat and barley grain. Environ. Pollut. 131:461-8. 